\title{
Some Vasoactive Mediators in Scorpion Envenomation of Children
}

\author{
Ramadan A. Sayed*, Zeinab M. Mohey **, Abdel-Raheim M. Abdel-Hafeez*, \\ Ahmad Y, Nassar* and Hussein M. Hussein*** \\ *Department of Biochemistry, Faculty of Medicine, Assiut University; \\ **Department of Pediatric, Faculty of Medicine, Assiut University \\ ***Department of Biochemistry, Faculty of Medicine, Al-Azhar University
}

\begin{abstract}
Scorpion envenomation in children is potentially fatal condition. Scorpion envenoming cause an autonomic storm resulting in a massive release of catecholamines, angiotensin II, glucagon and cortisol. As a consequance of these changes, scorpion envenoming result in a syndrome of fuel energy deficits, producing multi-system-organ failure and death. The objective of the present study was to determine circulating levels of adrenaline, nor-adrenaline, angiotensin converting enzyme (ACE), angiotensin II, kallikrein, nitric oxide (NO), aldosterone as well as $\mathrm{Na}^{+}, \mathrm{K}^{+}$and $\mathrm{Ca}^{+2}$ in scorpion envenomed children. The relationship between these vasoactive mediators and the severity of scorpion envenomation and the outcome of envenomed children would be evaluated. The present study included 40 scorpion envenomed children of both sexes and their age ranged 1-13 years. According to the severity of envenomation, they were divided into 2 groups, mild and severe. 10 apparently healthy children were considered as control group. All of them were subjected to complete clinical examination and routine laboratory investigations. Plasma levels of angiotensin II, adrenaline and nor-adrenaline were determined using ELISA assay. Serum aldosterone level was determined using RIA method. The enzyme activities of kallikrein and ACE and NO level were determined using spectrophotometric assay. Serum levels of $\mathrm{Na}^{+}$and $\mathrm{K}^{+}$were determined by flame photometer and $\mathrm{Ca}^{+2}$ by flame atomic absorption. All of these parameters were assayed on admission and after 24 hours. All envenomed children showed on admission significant increase in levels of angiotensin II, adrenaline and noradrenaline, ACE, NO, aldosterone and $\mathrm{Na}^{+}$in comparison with healthy control $(P<$ $0.01, P<0.01, P<0.01, P<0.01, P<0.01, P<0.01, P<0.001$ and $P<0.001)$ respectively. On the other hand, kallikrein activity, $\mathrm{K}^{+}$and $\mathrm{Ca}^{+2}$ levels were significantly decreased $(P<0.05, P<0.001$ and $P<0.05)$ respectively. However, on the second sample (after 24 hours) it was noted that the levels of ACE, angiotensin II and NO were still higher than those in healthy control $(P<0.05, P<0.001$ and $P$ $<0.05)$ respectively, but non significant difference was detected in kallikrein activity on comparing the second sample with healthy control. In conclusion, these vasoactive mediators might play an important role in pathogenesis of multi-systemorgan failure and death that occur with scorpion envenomation
\end{abstract}




\section{INTRODUCTION \& AIM OF THE WORK}

Neurotoxins and cardiotoxins are present in the majority of scorpion venoms $^{1}$. The clinical manifestations due to scorpion sting are believed to be primari1y due to complex interaction between sympathetic and parasympathetic stimulation ${ }^{2}$.

Severe scorpion envenoming causes an autonomic storm resulting in a massive release of catecholamines, angiotensin II (Ang II), glucagon, cortisol, and changes in insulin secretion. As a consequence of these changes in the hormonal milieu, scorpion envenoming results in a syndrome of fuel energy deficits and an inability of the vital organs to utilize the existing metabolic substrates, which causes myocardial damage, cardiovascular disturbances, peripheral circulatory failure, pulmonary edema, and many other clinical manifestations alone or in combination, producing multisystem organ failure (MSOF) and death ${ }^{3}$.

Nitric oxide (NO) plays a critical role in the regulation of vascular tone and organ blood flow as well as in the inhibition of platelets and neutrophils aggregation. However, excessive production of NO has been reported in several myocardial disorders involving inflammatory process such as endotoxic shock and heart failure ${ }^{4}$. Previously, Meki and Mohey-Eldeen, showed that NO levels were significantly higher in scorpion envenomed children compared to controls of the same age.

The aim of the present study was to determine circulating levels of adrenaline, noradrenaline, angiotensin converting enzyme (ACE), Ang II, kallikrein, nitric oxide, aldosterone and some electrolytes such as $\mathrm{Na}^{+}, \mathrm{K}^{+}$ and $\mathrm{Ca}^{+2}$ in scorpion envenomed children on admission and after 24 hours. The relationship between these vasoactive mediators and the severity of scorpion envenomation and the outcome of envenomed children would be evaluated.

\section{SUBJECTS \& METHODS}

\section{A. Subjects \\ (I) Patients:}

The present study included forty children with scorpion envenomation who, were admitted to the emergency unit and intensive care units (ICU) of Pediatric Department in Assiut university hospital. They included 24 males and 16 females. Their age ranged from 1 -13 years old.

The patients were classified into 2 main groups according to the degree of severity of envenomation either mild (Group I) comprising 22 patients were presented with pain, flushing, salivation, lacrimation, abdominal pain, tachycardia and mild irritability, or severe (Group II) comprising 18 patients were presenting with hypotension, heart failure (dyspnea, +ve hepatojugular reflux and basal crepitation), toxic myocarditis (dyspnea, heart failure, distant heart sound, ECG changes and echocardiography suggestive of myocardial ischemia, myocarditis and cardiomegally), pulmonary edema (dyspnea, cyanosis and bubbling lung crepitation), hallucinations and movements. 


\section{(II) Control group:}

Ten apparently healthy children of matchable age and sex were considered as controls.

\section{Sample preparation:}

Two blood samples were collected from each victim, one on admission and the second after 24 hours but only one sample was withdrawn from controls. One part of blood sample $(2 \mathrm{ml})$ was taken on anticoagulant (EDTA) and the rest of blood sample (3ml) was for serum preparation.

Out of all the studied cases,
before administration blood samples were withdrawn from 15 cases for determination of serum levels of aldosterone, $\mathrm{Na}^{+}, \mathrm{K}^{+}$and $\mathrm{Ca}^{+2}$.

Blood samples were centrifuged and the serum or plasma obtained was divided into aliquots and frozen at -70 $\mathrm{C}^{\circ}$ until assays were performed.

\section{B. Methods}

1. Determination of plasma adrenaline, noradrenaline and angiotensin II levels. Levels of these indices were determined by enzyme linked immunosorbent assay method (ELISA) Kit for the in vitro diagnostic separate quantitative determination of adrenaline and noradrenaline in human plasma and urine, supplied from Immuno Biological Laboratories (IBL), Cat.-No: RE59242, Germany and for detection of plasma level of Ang II, supplied from Peninsula Laboratories, INC. Division of Bachem, 601 Taylor Way, San Carlos, CA 94070 USA.

2. Determination of serum level of angiotensin converting enzyme. The activity of serum angiotensin converting enzyme (ACE) was determined by spectrophotometric method $^{6}$.

3. Determination of plasma kallikrein activity. The plasma kallikrein activity catalyses the splitting of p-nitroaniline (pNA) from the substrate H-D-Pro-Phe-Arg-pNA (S-2302). The rate at which the pNA is released is measured photometrically at $405 \mathrm{~nm}$. This can conveniently be read after stopping the reaction with acetic acid (acid stopped method).The activity measured is mainly the kallikrein- $\alpha 2$ macroglobulin complex ${ }^{7}$.

4. Determination of serum level of nitric oxide. The serum level of total nitric oxide (nitrate + nitrite) was determined by Griess reagent using spectrophotometric method ${ }^{8}$.

5. Determination of serum aldosterone. The Coat-A-Count aldosterone is a solid phase $\mathrm{I}^{125}$ radioimmunoassay (RIA) designed for the quantitative measurement of aldosterone levels in unextracted serum; coupled with an ethyl acetate extraction procedure. Cat. No: TKAL 1 (100 tubes).

6. Determination of serum levels of $\mathrm{Na}^{+}$and $\mathbf{K}^{+}$. Serum levels of $\mathrm{Na}^{+}$and $\mathrm{K}^{+}$were determined by Flame Photometer (Jenway- PFP7).

7. Determination of serum level of $\mathrm{Ca}^{+2}$. Serum level of $\mathrm{Ca}^{+2}$ was determined by Atomic absorption flame, Emission spectrophotometer (Shimadzu - AA-630-02) at WL $422.7 \mathrm{~nm}$ and lamp current $10 \mathrm{~A}^{\circ}$.

Statistical analysis

The results were statistically analyzed using computer database (Prism program, Graphpad version 3.0). Data comparisons were performed by using student t-test and 
the correlations between the biochemical parameters were performed using Spearman's rank correlation coefficient. The levels of significance were accepted with $\mathrm{P}<$ 0.05 and the results were presented in Tables as mean \pm SE.

\section{RESULTS}

The current results showed that all envenomed children showed significant higher mean value of circulating levels of each of adrenaline, noradrenaline, ACE Ang II and NO on admission (first sample) in comparison with healthy controls. On the other hand, the envenomed victims showed significantly lower mean value of kallikrein activity on admission in comparison with healthy controls. However, on the second sample it was noted that the circulating levels of ACE, Ang II and NO were still significantly higher than those of control group (Table 1).

The mild envenomed children showed significant elevation of adrenaline and noradrenaline on admission in comparison with controls. One day later the plasma level of adrenaline was still significantly higher in mild envenenomed children than controls, but non-significant difference was found on comparing second sample of noradrenaline with controls. However, ACE activity and Ang II levels were significantly elevated in the first sample in comparison with controls. Moreover, ACE activity and Ang II levels were significantly elevated on comparing second samples and controls. The envenomed children showed significant decrease of mean value of plasma kallikrein activity on admission in comparison with controls, but non-significant differences were detected in comparison of second samples with controls. The envenomed children showed significant elevation of NO on admission in comparison with controls, but non-significant difference was detected on comparing second sample and controls (Table 2).

In severe envenomed children, adrenaline and noradrenaline showed significant elevation on admission in comparison with controls. Nonsignificant differences were shown between second samples of adrenaline and noradrenaline with controls. ACE activity and Ang II levels were significantly elevated in the first samples in comparison with controls. Moreover, the plasma level of Ang II still significantly elevated in the second samples in comparison with controls. Furthermore, the envenomed children showed significant decrease of mean value of plasma kallikrein activity on admission in comparison with controls, but the second sample showed non-significant difference of kallikrein than controls. The serum level of NO showed significant elevation on admission and after 24 hours in envenomed children in comparison with controls (Table 3).

All envenomed children $(n=40)$ on admission showed significant elevation of aldosterone and $\mathrm{Na}^{+}$and significant decrease of $\mathrm{K}^{+}$and $\mathrm{Ca}^{+2}$ in comparison with controls (Table 4).

The severe envenomed children showed significant decrease of adrenaline and noradrenaline in the second samples in comparison with 
mild cases. The circulating levels of ACE and Ang II showed significant decrease of mean value on comparing second samples of severe envenomed children with mild cases. In addition the severe envenomed children showed significant elevation of circulating levels of kallikrein activity and NO in the second samples in comparison with mild cases (Table 5).
The non-survival envenomed victims after 24 hours showed significant decrease of adrenaline, noradrenaline and Ang II levels in comparison with survival. Kallikrein showed significant elevation of mean value in non-survival cases in comparison with survival cases. Nitric oxide showed significant elevation on admission and after 24 hours between non-survival cases and survival cases (Table 6).

Table (1): A comprehensive table for biochemical parameters determined in envenomed children with reference to controls (mean $\pm \mathrm{SE}$ ).

\begin{tabular}{|c|c|c|c|c|c|}
\hline \multirow{2}{*}{$\begin{array}{l}\text { Biochemical } \\
\text { parameters }\end{array}$} & \multicolumn{2}{|c|}{$\begin{array}{l}\text { Envenomed children } \\
(n=40)\end{array}$} & \multirow{2}{*}{$\begin{array}{l}\text { Healthy } \\
\text { controls } \\
(\mathrm{n}=10)\end{array}$} & \multicolumn{2}{|c|}{ P-Values } \\
\hline & 1st sample & 2nd sample & & $P_{1}$ & $\boldsymbol{P}_{2}$ \\
\hline Adrenaline (ng/ml) & $0.25 \pm 0.014$ & $0.20 \pm 0.01$ & $0.16 \pm 0.015$ & $<0.01$ & $>0.05(\mathrm{NS})$ \\
\hline Noradrenaline (ng/ml) & $0.78 \pm 0.05$ & $0.57 \pm 0.03$ & $0.47 \pm 0.07$ & $<0.01$ & $>0.05$ (NS) \\
\hline ACE (U/l) & $299.40 \pm 29.61$ & $257.9 \pm 28.26$ & $130.0 \pm 15.74$ & $<0.01$ & $<0.05$ \\
\hline Ang II (ng/ml) & $4.97 \pm 0.63$ & $5.138 \pm 0.5130$ & $1.78 \pm 0.07$ & $<0.01$ & $<0.001$ \\
\hline Kallikrein (U/l) & $283.0 \pm 26.11$ & $339.5 \pm 30.20$ & $399.0 \pm 35.95$ & $<0.05$ & $>0.05(\mathrm{NS})$ \\
\hline $\mathrm{NO}(\mu \mathrm{M} / \mathrm{L})$ & $117.0 \pm 13.45$ & $102.8 \pm 12.50$ & $50.64 \pm 6.13$ & $<0.01$ & $<0.05$ \\
\hline
\end{tabular}

$P_{1}$, first sample versus control group.

$\mathrm{P}_{2}$, second sample versus control group.

NS, Non significant.

Table (2): The levels of the studied biochemical parameters in children with mild envenomation in comparison to controls (mean $\pm \mathrm{SE}$ ).

\begin{tabular}{|c|c|c|c|c|c|}
\hline \multirow{2}{*}{$\begin{array}{l}\text { Biochemical } \\
\text { parameters }\end{array}$} & \multicolumn{2}{|c|}{ Envenomed mild cases $(n=22)$} & \multirow{2}{*}{$\begin{array}{c}\text { Healthy } \\
\text { controls } \\
(n=10)\end{array}$} & \multicolumn{2}{|c|}{ P-Values } \\
\hline & 1st sample & 2nd sample & & $P_{1}$ & $P_{2}$ \\
\hline Adrenaline (ng/ml) & $0.27 \pm 0.02$ & $0.22 \pm 0.01$ & $0.16 \pm 0.01$ & $<0.01$ & $<0.05$ \\
\hline Noradrenaline (ng/ml) & $0.76 \pm 0.10$ & $0.68 \pm 0.06$ & $0.47 \pm 0.07$ & $<0.05$ & $>0.05$ (NS) \\
\hline ACE (U/I) & $284.2 \pm 39.38$ & $329.5 \pm 40.91$ & $130.0 \pm 15.74$ & $<0.01$ & $<0.01$ \\
\hline Ang II (ng/ml) & $4.24 \pm 1.07$ & $6.800 \pm 0.98$ & $1.78 \pm 0.07$ & $<0.05$ & $<0.001$ \\
\hline Kallikrein (U/l) & $296.3 \pm 29.04$ & $285.2 \pm 31.08$ & $399.0 \pm 35.95$ & $<0.05$ & $<0.05$ \\
\hline NO $(\mu \mathrm{M} / \mathrm{l})$ & $85.47 \pm 7.87$ & $71.10 \pm 6.44$ & $50.64 \pm 6.132$ & $<0.01$ & $>0.05$ (NS) \\
\hline
\end{tabular}


Table (3): The levels of the studied biochemical parameters in children with severe envenomation in comparison to controls (mean $\pm \mathrm{SE}$ ).

\begin{tabular}{|c|c|c|c|c|c|}
\hline \multirow{2}{*}{$\begin{array}{l}\text { Biochemical } \\
\text { parameters }\end{array}$} & \multicolumn{2}{|c|}{ Envenomed severe cases $(n=18)$} & \multirow{2}{*}{$\begin{array}{l}\text { Healthy } \\
\text { controls } \\
(n=10)\end{array}$} & \multicolumn{2}{|c|}{ P-Values } \\
\hline & 1st sample & 2nd sample & & $P_{1}$ & $\boldsymbol{P}_{2}$ \\
\hline Adrenaline (ng/ml) & $0.23 \pm 0.01$ & $0.16 \pm 0.01$ & $0.16 \pm 0.01$ & $<0.01$ & $>0.05(\mathrm{NS})$ \\
\hline Noradrenaline (ng/ml) & $0.80 \pm 0.05$ & $0.52 \pm 0.02$ & $0.47 \pm 0.07$ & $<0.01$ & $>0.05$ (NS) \\
\hline ACE (U/l) & $318.10 \pm 45.72$ & $188.4 \pm 27.24$ & $130.0 \pm 15.74$ & $<0.01$ & $>0.05(\mathrm{NS})$ \\
\hline Ang II (ng/ml) & $5.42 \pm 0.78$ & $4.12 \pm 0.44$ & $1.78 \pm 0.07$ & $<0.01$ & $<0.001$ \\
\hline Kallikrein (U/l) & $283.0 \pm 26.11$ & $424.9 \pm 54.26$ & $399.0 \pm 35.95$ & $<0.05$ & $>0.05(\mathrm{NS})$ \\
\hline $\mathrm{NO}(\mu \mathrm{M} / \mathrm{l})$ & $124.8 \pm 22.58$ & $136.9 \pm 22.97$ & $50.64 \pm 6.13$ & $<0.05$ & $<0.01$ \\
\hline
\end{tabular}

$P_{1}$, first sample versus control group.

$P_{2}$, second sample versus control group.

NS, Non significant.

Table (4): The serum levels of aldosterone, $\mathrm{Na}^{+}, \mathrm{K}^{+}$and $\mathrm{Ca}^{+2}$ in envenomed children before fluid administration in comparison with controls (mean $\pm \mathrm{SE}$ ).

\begin{tabular}{|l|l|l|l|}
\hline Biochemical parameters & $\begin{array}{l}\text { Envenomed } \\
\text { children }(\mathbf{n}=\mathbf{4 0})\end{array}$ & $\begin{array}{l}\text { Healthy controls } \\
(\mathbf{n = 1 0})\end{array}$ & P-Value \\
\hline Aldosterone (ng/dl) & $27.71 \pm 3.25$ & $4.50 \pm 0.49$ & $<0.001$ \\
\hline $\mathrm{Na}^{+}(\mathrm{nmol} / \mathrm{l})$ & $153.16 \pm 0.65$ & $140.15 \pm 0.54$ & $<0.001$ \\
\hline $\mathrm{K}^{+}(\mathrm{nmol} / \mathrm{l})$ & $3.54 \pm 0.008$ & $5.29 \pm 0.15$ & $<0.001$ \\
\hline $\mathrm{Ca}^{+2}(\mathrm{mg} / \mathrm{dl})$ & $7.10 \pm 0.80$ & $9.80 \pm 0.60$ & $<0.05$ \\
\hline
\end{tabular}


Table (5): The comparative biochemical parameters among mild and severe envenomed children.

\begin{tabular}{|c|c|c|c|c|c|c|c|c|c|c|c|c|}
\hline \multirow{3}{*}{$\begin{array}{l}\text { Envenomed } \\
\text { Children }\end{array}$} & \multicolumn{12}{|c|}{ Biochemical parameters } \\
\hline & \multicolumn{2}{|c|}{ Adrenaline } & \multicolumn{2}{|c|}{ Nor-adrenaline } & \multicolumn{2}{|l|}{ ACE } & \multicolumn{2}{|c|}{ Ang II } & \multicolumn{2}{|c|}{ Kallikrein } & \multicolumn{2}{|l|}{ NO } \\
\hline & 1st & 2nd & 1st & 2nd & 1st & 2nd & 1st & 2nd & 1st & 2nd & 1st & 2nd \\
\hline $\begin{array}{l}\text { Mild cases } \\
(n=22)\end{array}$ & $\begin{array}{l}0.27 \pm \\
0.02 \\
\end{array}$ & $\begin{array}{l}0.22 \pm \\
0.01 \\
\end{array}$ & $\begin{array}{l}0.76 \pm \\
0.10 \\
\end{array}$ & $\begin{array}{l}0.68 \pm \\
0.06 \\
\end{array}$ & $\begin{array}{l}284.2 \pm \\
39.38 \\
\end{array}$ & $\begin{array}{l}329.50 \pm \\
40.91\end{array}$ & $\begin{array}{l}4.25 \pm \\
1.07 \\
\end{array}$ & $\begin{array}{l}6.80 \pm \\
0.98 \\
\end{array}$ & $\begin{array}{l}296.30 \pm \\
29.04 \\
\end{array}$ & $\begin{array}{l}285.20 \pm \\
31.08 \\
\end{array}$ & $\begin{array}{ll}85.47 \quad \pm \\
7.87 & \\
\end{array}$ & $\begin{array}{l}71.10 \pm \\
6.44 \\
\end{array}$ \\
\hline $\begin{array}{l}\text { Severe cases } \\
(\mathrm{n}=18)\end{array}$ & $\begin{array}{l}0.23 \pm \\
0.01 \\
\end{array}$ & $\begin{array}{l}0.16 \pm \\
0.01 \\
\end{array}$ & $\begin{array}{l}0.80 \pm \\
0.05 \\
\end{array}$ & $\begin{array}{l}0.52 \pm \\
0.02 \\
\end{array}$ & $\begin{array}{l}318.10 \pm \\
45.72\end{array}$ & $\begin{array}{l}188.40 \pm \\
27.24\end{array}$ & $\begin{array}{l}5.42 \pm \\
0.78 \\
\end{array}$ & $\begin{array}{l}4.12 \pm \\
0.44 \\
\end{array}$ & $\begin{array}{l}283.0 \pm \\
26.11 \\
\end{array}$ & $\begin{array}{l}424.90 \pm \\
54.26\end{array}$ & $\begin{array}{l}124.8 \pm \\
22.58 \\
\end{array}$ & $\begin{array}{l}136.9 \pm \\
22.97 \\
\end{array}$ \\
\hline P-Value & (NS) & $<0.05$ & (NS) & $<0.05$ & (NS) & $<0.01$ & (NS) & $<0.01$ & (NS) & $<0.05$ & (NS) & $<0.01$ \\
\hline
\end{tabular}

The results are expressed as mean \pm SE. NS: Non-significant.1st: First determination on admission, 2nd: Second determination after 24 hours of admission.

Table (6): The comparative biochemical parameters among survival and non-survival cases.

\begin{tabular}{|c|c|c|c|c|c|c|c|c|c|c|c|c|}
\hline \multirow{3}{*}{$\begin{array}{l}\text { Envenomed } \\
\text { children }\end{array}$} & \multicolumn{12}{|c|}{ Biochemical parameters } \\
\hline & \multicolumn{2}{|c|}{ Adrenaline } & \multicolumn{2}{|c|}{ Nor-adrenaline } & \multicolumn{2}{|c|}{ ACE } & \multicolumn{2}{|c|}{ Ang II } & \multicolumn{2}{|c|}{ Kallikrein } & \multicolumn{2}{|c|}{ NO } \\
\hline & 1st & 2nd & 1st & 2nd & 1st & 2nd & 1st & 2nd & 1st & 2nd & 1st & 2nd \\
\hline $\begin{array}{l}\text { Survival cases } \\
(n=12)\end{array}$ & $\begin{array}{l}0.24 \pm \\
0.02\end{array}$ & $\begin{array}{l}0.19 \pm \\
0.02\end{array}$ & $\begin{array}{l}0.68 \pm \\
0.03\end{array}$ & $\begin{array}{l}0.57 \pm \\
0.02\end{array}$ & $\begin{array}{l}285.40 \pm \\
63.18\end{array}$ & $\begin{array}{l}277.90 \pm \\
62.33\end{array}$ & $\begin{array}{l}4.775 \pm \\
0.8641\end{array}$ & $\begin{array}{l}5.88 \pm \\
0.67\end{array}$ & $\begin{array}{l}242.80 \pm \\
54.95\end{array}$ & $\begin{array}{l}364.50 \pm \\
38.84\end{array}$ & $\begin{array}{l}79.27 \pm \\
9.99\end{array}$ & $\begin{array}{l}86.38 \pm \\
13.30\end{array}$ \\
\hline $\begin{array}{l}\text { Non-surv. } \\
(n=6)\end{array}$ & $\begin{array}{l}0.22 \pm \\
0.01\end{array}$ & $\begin{array}{l}0.13 \pm \\
0.01\end{array}$ & $\begin{array}{l}0.89 \pm \\
0.10\end{array}$ & $\begin{array}{l}0.46 \pm \\
0.03\end{array}$ & $\begin{array}{l}383.30 \pm \\
49.86\end{array}$ & $\begin{array}{l}159.3 \pm \\
21.47 \\
\end{array}$ & $\begin{array}{l}6.70 \pm \\
1.56\end{array}$ & $\begin{array}{l}3.50 \pm \\
0.69\end{array}$ & $\begin{array}{l}364.90 \pm \\
101.60\end{array}$ & $\begin{array}{l}603.50 \pm \\
84.12\end{array}$ & $\begin{array}{l}215.9 \pm \\
47.63 \\
\end{array}$ & $\begin{array}{l}237.8 \pm \\
39.33\end{array}$ \\
\hline P-Value & (NS) & $<0.05$ & (NS) & $<0.05$ & $(\mathrm{NS})$ & (NS) & (NS) & $<0.05$ & (NS) & $<0.01$ & $<0.001$ & $<0.001$ \\
\hline
\end{tabular}

The results are expressed as mean \pm SE, NS: Non-significant, 1st: First determination on admission, 2nd: Second determination after 24 hours of admission 
Table (7): The correlation between different variables in envenomed children

\begin{tabular}{|l|l|l|}
\hline Variables & Admission sample & After 24 hr sample \\
\hline Adrenaline and & $\mathrm{r}=0.81$ & $\mathrm{r}=0.65$ \\
Noradrenaline & $\mathrm{P}<0.001$ & $\mathrm{P}<0.01$ \\
\hline Noradrenaline and & $\mathrm{r}=0.62$ & $\mathrm{r}=0.66$ \\
Ang II & $\mathrm{P}<0.01$ & $\mathrm{P}<0.01$ \\
\hline Ang II and & $\mathrm{r}=0.79$ & $\mathrm{r}=0.5$ \\
ACE & $\mathrm{P}<0.001$ & $\mathrm{P}<0.01$ \\
\hline Kallikrein and & $\mathrm{NS}$ & $\mathrm{r}=0.4$ \\
NO & & $\mathrm{P}<0.05$ \\
\hline
\end{tabular}

$r$ means correlation coefficients

$P$ means levels of significance

NS means non significant

\section{DISCUSSION}

Scorpion envenomation in children is a potentially fatal condition. Neurotoxins and cardiotoxins are present in the majority of scorpion venoms ${ }^{9}$. The symptoms and signs of envenomation are believed to be primari1y due to complex interaction between sympathetic and parasympathetic stimulation ${ }^{\mathbf{1 0}}$.

The mechanisms by which scorpion envenomation provokes sympathetic nervous system activation are probably mixed. Experimental studies indicated that scorpion venom induces the release of noradrenaline and acetylcholine by acting at peripheral pre-synaptic and afferent visceral receptors ${ }^{11}$. However, the venom of certain species may provoke apnea, bradycardia and hypotension as the main manifestations of the envenomation $^{12-13}$. In addition Chen et al. $^{\mathbf{1 4}}$ showed that scorpion venom caused (a dose-dependent) increase in blood pressure in experimental rats, which may be related to overproduction of noradrenaline.
Cardiac dysfunction and pulmonary edema are the leading causes of death related to scorpion envenomation $^{15-16}$. The mechanisms responsible for the toxic actions of the scorpion venom on the cardiovascular system are still the subject of intense controversy and research. Most investigators consider that, the cardiovascular manifestations (i.e. pulmonary edema and shock) are secondary to the peripheral vascular and myocardial effects of scorpion envenomation $^{11}$. A syndrome of systemic inflammatory response to the venom has also been postulated as an explanation for the cardiovascular manifestations ${ }^{\mathbf{1 7}}$.

Scorpion envenomation induces cardiac dysfunction ${ }^{11}$. Murthy ${ }^{18}$, hypothesized that catecholamine storm post envenomation may cause cardiac dysfunction by catecholamineinduced hypoxia and death might result from myocarditis and congestive heart failure. Some authors suggested that cardiac dysfunction in scorpion envenomation may be due to a direct effect of scorpion venom 
evoking the so-called scorpionic myocarditis characterized by nonspecific ultra-structural changes ${ }^{\mathbf{1 9}}$. Moreover, Nouira et al. ${ }^{20}$ reported that heart failure was observed in clinical studies dealing with cardiocirculatory disturbances associated with severe scorpion envenomation.

In the present study as shown in tables (1, 2 and 3), the plasma levels of adrenaline and noradrenaline were significantly raised in all envenomed children on admission in comparison to controls, but after 24 hours they showed reversible decline from that attitude. Moreover, severe and nonsurvivors showed significantly lower mean values after 24 hours than mild and survivors respectively (Tables 5 and 6). These results seem to be in consistency with that of Mazzei et $\mathrm{al}^{21}$ who reported that plasma noradrenaline was elevated on admission and decreased after 24 hours in scorpion envenomed patients. Moreover Zeghal et al., ${ }^{22}$ stated that scorpion venom induced a 30-40-fold increase in plasma adrenaline and nor adrenaline levels in anaesthetized rats.

Mahadevan $^{23}$, reported that scorpion envenoming results in a massive release of catecholamines, glucagon, Ang II and a simultaneous reduction in insulin levels, which finally cause multi-organ system failure and death. Scorpion envenomation is currently considered to resemble the massive outpouring of catecholamines seen in phaeochromocytoma crises ${ }^{24}$. Cheng $^{25}$, reported that most of the neurological symptoms are due to either the release of catecholamines from the adrenal glands (sympathetic nerves) or the release of acetylcholine from postganglionic parasympathetic neurons.

Moreover, Murthy et al. ${ }^{26}$ reported that after scorpion envenoming there were massive release of catecholamines, causing increased myocardial oxygen consumption, coronary vasoconstriction, peripheral vasoconstriction and lipoloysis resulting in increased FFA along with a simultaneous reduction in triglyceride levels. The utilization of increased amounts of circulating FFA results in increased oxygen consumption that could aggravate ischemic injury to the myocardium, predisposing to arrhythmias and heart failure. In addition Gueron et al. ${ }^{15}$ hypothesized that catecholamine storm post envenomation may cause cardiac dysfunction by catecholamine -induced hypoxia and that death might result from myocarditis and congestive heart failure. On the another hand, some investigators suggested that cardiac dysfunction in scorpion envenomation may be due to a direct effect of scorpion venom evoking the so-called scorpionic myocarditis characterized by nonspecific ultra-structural changes ${ }^{19 \& 27}$. Furthermore, Nouira et al. ${ }^{20}$ showed that the presence of right and left ventricular dysfunction after scorpion envenomation provided further augmentation to the hypothesis of scorpionic myocarditis.

The assayed catecholamines were highly proportional to each other (Table 7) in these envenomed children, similar to the results of Rumantir et al. ${ }^{28}$, since they are coreleased from sympathetic neurons. On the other hand Thomas et al. ${ }^{29}$ believe that adrenaline augments the 
release of noradrenaline from sympathetic stimulation of presynaptic receptors.

In the present work as shown in tables (1, 2 and 3), the ACE activities and Ang II levels were significantly elevated on admission in all victims in comparison to controls. After 24 hours they were still higher. Furthermore, the circulating levels of ACE activity and Ang II were significantly lower in the second samples of severe and nonsurvivor envenomed victims in comparison with mild and survivor cases respectively. These results are mostly matched with those El-Kady et al. ${ }^{30}$ who stated that there was significant increase in enzyme activity of ACE in all envenomed children in comparison to controls. Moreover these bioindices were significantly higher in hypertensive victims in comparison to normotensive ones. In that field, many investigators recognized similar findings ${ }^{15,18 \& 31}$.

The mechanism by which Ang II elevate blood pressure is probably through vasoconstriction, salt and water reabsorption and aldosterone secretion. Ang II also, increases blood pressure through actions on the brain and autonomic nervous system. In particular, it acts centrally to increase sympathetic outflow and peripherally to facilitate sympathetic transmission by increasing the release and reducing the reuptake of noradrenaline at adrenergic nerve terminals ${ }^{32}$.

Generally, it is believed that scorpion envenomation results in a severe autonomic storm, which leads to a massive release of catecholamines. Then increased sympathetic activity causes elevated renin release by direct stimulation of juxtaglomerular cells. A subsequent increase in angiotensin secretion enhances the ongoing sympathetic nerve output by a direct action on the brain stem and by a blunting of baroreceptor mechanisms. Thus, the renin angiotensin system is an important facilitator of ongoing sympathoadrenal traffic ${ }^{15 \& 31}$. Such finding is confirmed in the present study as there were significant positive correlation between the values of noradrenaline and Ang II on admission as well as after 24 hours of all envenomed victims (Table 7).

Angiotensin converting enzyme is known to produce Ang II, which may cause potent coronary and systemic vasoconstriction $^{33}$. Ang II, the primary effector of the renin-angiotensin system (RAS), is a multifunctional hormone that plays an important role in vascular function. The local RAS, acting in both autocrine and paracrine fashions, is also functionally operative, and, important in the vasculature $^{34}$. In that respect, the significant correlation between ACE and Ang II in the studied envenomed children (Table 7) confirms that plasma and/or tissue ACE is the major enzyme responsible for generation of the vasoconstrictor peptide Ang II from Ang ${ }^{35}$.

Concomitantly, angiotensin converting enzyme (ACE) inhibitors were suggested to be useful in scorpion envenoming with elevated Ang II level ${ }^{36}$.

High molecular weight kininogen (HMW) and low molecular weight kininogen (LMW) are the two substrates for the kallikrein. HMW kininogen is cleaved by plasma and tissue kallikrein to yield bradykinin 
and kallidine respectively. LMW kininogen is a substrate only for tissue kallikrein and the product is kallidine 37. Campbell ${ }^{38}$, showed that in man, the generation of bradykinin and kallidine peptides by plasma and tissue kallikrein, respectively, enables differentiation between the role of plasma and tissue kallikrein in kinin peptide formation.

As regard kallikrein enzyme in the present study, the kallikrein activities were significantly decreased in all victims on admission in comparison to controls but after 24 hours the severe envenomed children showed reversible elevation as shown in tables 1, 2 and 3. Such data seems to be in accordance with those McGiff et al. ${ }^{39}$ who showed that urinary kallikrein concentration was decreased in individual with high blood pressure. Accordingly, the recorded hypertension in all admitted envenomed children could partially be related to considerable decrease in plasma kallikrein activity associated with ACE enhancement and Ang II accumulation.

Furthermore, in the second sample the severe envenomed as well as the non-survivors children exhibited significantly higher mean value of plasma kallikrein activity than mild and the survivors respectively as shown in tables (5 and 6).

Since, HMW cleaved by plasma kallikrein gives bradykinin and according to McGiff et al. ${ }^{39}$ this bradykinin can promote vasodilatation, through $\beta_{2}$ receptors dependent effects on endothelial NO, prostacycline and the poorly characterized endothelium derived hyperpolarizing factor. In this respect,
Ismail $^{\mathbf{1 0}}$, suggested that kinins and/ or prostaglandins may participate in the genesis of terminal hypotension in scorpion envenomation. Previously, Ismail et al. $^{40}$ had indicated that kallikrein inhibitor (aprotinin) prolonged the survival time of rats against Leiurus quinquestriatus toxicity, and was able to rescue half of the animal from the lethal action of the scorpion venom.

Nitric oxide, as an endogenous endothelium-derived relaxing factor has also been extensively studied, NO, plays critical roles in the maintenance of vascular homeostasis. In the vasculature, Ang II and NO interact with each other to influence each other's functions ${ }^{41}$. NO is too short lived to be measured directly and so evidence of increased NO production is necessarily indirect. Serum concentration of nitrites and/or nitrates is commonly used in clinical studies to measure NO production ${ }^{42}$.

The serum levels of determined NO in all victims were significantly elevated on admission and after 24 hours than controls as shown in tables (1, 2 and 3). Furthermore, this level was differentially more elevated in severe cases after 24 hours, specifically the non-survivors as shown in tables (5 and 6).

These findings agree with those of the investigators who found significant higher mean level of NO in all envenomed children (both severe and mild cases) in comparison to controls and that elevation was positively correlated with the severity of envenomation ${ }^{5 \& 27}$

The constitutive isoform of the NO is believed to be enhanced by acetylcholine and bradykinin ${ }^{43}$. 
Accordingly, the determined elevated kallikrein in the envenomed severe cases after 24 hours may enhance an accumulation of bradykinin which predictably promoted the endogenous cNOS to produce further NO molecules. Anyhow, the determined correlation between the kallikrein level and that of accumulated NO in the second samples (Table 7) may denote to such a mutual relation between kallikrein and possible activation of cNOS.

Simultaneously, Busse et al. $^{43}$ stated that synthesized NO by NOS is regulated by local concentration of BK, which acts on $\beta_{2}$ receptors on the endothelial cells surface membrane. This BK is regulated by ACE that breaks down BK into inactive peptide. Hence, high ACE concentrations will antagonize NO activity ${ }^{44-45}$. In addition, Teixeira et al. $^{46}$ found that NO molecules accumulated from human corpus cavernosum induced by a purified scorpion toxin.

Aldosterone regulates electrolyte excretion and intravascular volume mainly through its effects on the renal distal convoluted tubules and cortical collecting duct, where it acts to increase resorption of $\mathrm{Na}^{+}$from the urine. Aldosterone, also, enhances the synthesis of a $\mathrm{Na}^{+} / \mathrm{K}^{+}$ATPase located in the basolateral cell membrane, which generates the electrochemical gradient, which drives diffusion through the $\mathrm{Na}^{+}$channels ${ }^{47}$.

The envenomed children on admission showed significant elevation in serum aldosterone level in comparison to controls (Table 4). Gueron et al. ${ }^{15}$ found that the blood aldosterone level was elevated in patients after scorpion envenomation.
Some clarified that the elevation in aldosterone serum level may be due to Ang II which is the principal stimulator of aldosterone production ${ }^{\mathbf{4 8}}$. Hence, recorded increase in Ang II in envenomed children could be an increasing factor for elevation of serum aldosterone.

Electrolyte disturbances are common finding in victims of scorpion envenomation ${ }^{10 \& 18}$. Serum $\mathrm{Na}^{+}$level in the envenomed children on admission was significantly increased (Table 4) as it was found before by El-Kady et al. ${ }^{30}$. They found that this increase was more prominent in hypertensive envenomed victims. Ang II causes salt and water retention, either by direct effect on kidneys or through its action on the adrenal glands to secrete aldosterone, which in turn increases $\mathrm{Na}^{+}$and water reabsorbtion by the kidney tubules. The arterial blood pressure may rise to a considerably increased level to overcome these two fluid retaining effects of Ang $\mathrm{II}^{49}$.

The serum level of $\mathrm{K}^{+}$reversibly showed significant decrease in these envenomed children (Table 4), also, El-Kady et al. ${ }^{30}$ have reported a similar result. In an opposite manner Ismail, ${ }^{\mathbf{1 0}}$ observed hyperkalemia in sting victims and experimental animals injected with scorpion venom. Murthy, ${ }^{18}$ had deduced similar results after of injection of BT venom in dogs.

The serum $\mathrm{Ca}^{+2}$ level was significantly reduced in all of these envenomed victims which is in accordance to El-Kady et al. ${ }^{30}$ who attributed this hypocalcaemia to $\mathrm{Ca}^{+2}$ influx into the excitable cells including heart cells resulting in 
myocardial damage. Generally, Semir et al. $^{\mathbf{5 0}}$ suggested that electrolyte disturbances are due to the release of various mediators such as catecholamines, which directly affect $\mathrm{Na}^{+} / \mathrm{K}^{+}$adenosine triphosphatase and cellular $\mathrm{K}^{+}$distribution.

\section{REFERENCES}

1. Freire-Maia $L$. and Campos JA. (1987): Response to the letter to the Editor by Gueron and Ovsyshcher on the treatment of the cardiovascular manifestations of scorpion envenomation. Toxico. 25: 125-130.

2. Bawaskar HS. and Bawaskar PH. (2003): Clinical profile of severe scorpion envenomation in children at rural setting. Indian Pediatr., 40 (11): 1072-1075.

3. Murthy R. K. (2002): Scorpion envenoming syndrome. Problems of medical ethics and accountability in medical research in India. J. Venom. Anim. Toxi., 8 (1).

4. Lecour S., Maupoil V. and Zeller M. (2001): Levels of nitric oxide in the heart after experimental myocardial ischemia. J. Cardiovascular Pharmacol., 37: 55-63.

5. Meki AR. M. and Mohey ELDeen ZM. (1998): Serum interleukin 1 beta, interleukin-6, nitric oxide and alpha antitrypsin in scorpion envenomed children. Toxico., 36: 1851-1859.

6. Maguire GA. and Price CP. (1985): A continuous monitoring spectrophotometric methods for the measurement of angiotensin converting enzyme in human serum. Ann Clin Biochem., 22: 204-210.

7. Groth T., Synowitz J., Malsch G., Richau K., Albrecht W., Lange KP. and Paul D. (1997): Contact activation of plasmatic coagulation on polymeric membranes measured by the activity of kallikrein in heparinized plasma. J Biomater Sci Polym., 8 (10): 797-807.

8. Van Bezooijen RL., Que I., Ederveen AG., Kloosterboer HJ., Papapoulos SE. and Lowik CW. (1998): Plasma nitrate + nitrite level are regulated by ovarian steroids but do not correlate with trabecular bone mineral density in rats. J. Endocrinol., 159: 27-34.

9. Muller G. J. (1993): Scorpionism in South Africa: a report of 42 serious scorpion envenomation. S Africa. Med. J., 83 (6): 405-411.

10. Ismail M. (1995): The scorpion envenoming syndrome. Toxico., 33: 825-858.

11. Carmen A., Mazzei D., Diego F. D., Jose H. D., Gabriela A. B., Vanesa V. and Juan S. B. (2002): Sympathetic nervous system activation, antivenin administration and cardiovascular manifestations of scorpion envenomation. Toxic., 40 (9): 1339-1346.

12. Bagchi S. and Deshpande S. B. (1998): Indian red scorpion (Buthus tamulus) venom-induced augmentation of cardiac reflexes is mediated through the mechanisms involving kinins in urethane anaesthetized rats. Toxic., 36: 309-320. 
13. Shapira M. H., Aviv Y. S. and Sviri S. (1998): Second degree atrio-ventricular block and cardiotoxicity secondary to envenomation by the scorpion Leirus quinquestriatus (yellow scorpion')—an indication for serotherapy?. Human Exp. Toxicol., 17: 541-543.

14. Chen J. W. C., Shi M. J., Teng A. C., Schloithe J., Toouli and Saccone G. T. P. (2004): Scorpion venom stimulates biliary/duodenal motility and pancreatic exocrine secretion. Neurogastroenterol Motil., 16: 447-454.

15. Gueron H., Ilia R., Shahak E. and Sofer S. (1992): Renin and aldosterone levels and hypertension following envenomation in humans by the yellow scorpion Leiurus quinquestriatus. Toxico., 30 (7): 765-767.

16. Mazzei D. CA., Fuenmayor N., Salgar Z., Gonzales and Dàvila D.F. (1997): Scorpion envenomation in Mérida, Venezuela. Toxic., 35: 14591462.

17. Magalhaes M., Pereira C. F., Amaral N., Rezende and Campolina D. (1999): Serum levels of cytokines in patients envenomed with Tityus serrulatus scorpion sting. Toxic., 37: 11551164.

18. Murthy R. K. (2000): The scorpion envenoming syndrome: a different perspective. The physiological basis of the role of insulin in scorpion envenoming. J. Venom. Anim. Toxin., 6: 4-51.
19. Trasiuk A., Sofer S. and Huberfelo S. (1994): Haemodynamic effects following injection of venom from the scorpion Leirus quinquetriatus. J Crit Care., 9: 134-140.

20. Nouira S., Abroug F. and Haguiga H. (1995): Right ventricular dysfunction following severe scorpion envenomation. Ches., 108: 682-687.

21. Mazzei D. CA., Davila DF., Donis JH., de Bellabarba GA., Villarreal V. and Barboza JS. (2002): Sympathetic nervous system activation, antivenin administration and cardiovascular manifestations of scorpion envenomation. Toxic., 40 (9): 1339-1346.

22. Zeghal K., Sahnoun, Guinot M., Richer C. and Giudicelli J. F. (2000): Characterization and mechanisms of the cardiovascular and haemodynamic alterations induced by scorpion venom in rats. Fund Clin. Pharmacol., 14 (4): 351-361.

23. Mahadevan S. (2000): Scorpion Sting: Ind. Pediatr., 37: 504-514.

24. Gueron R., Illia R. and Margulia G. (2000): Arthropod poisons and the cardiovascular system. Am. J. Emerg. Med., 18: 708-714.

25. Cheng D. (2002): Scorpion sting. Last Updated, 18 (6): 1- 10.

26. Murthy R. K., Zare A. M. and Lida H. (1999): The use of serotherapy to reverse ECG and cardiac enzyme changes caused by scorpion Mesobuthus tamulus concanesis, Pocock envenoming. J. Venom. Anim. Toxin., 5: 154171. 
27. Meki AR. M., Mohey El-deen Z. M. and Mohey El-deen $H$. M. (2003): Significance of assessment of cardiac troponin I and interleukin-8 in scorpion envenomed children. Toxicon, 41: 129-137.

28. Rumantir MS., Jennings GL. and Lambert GW. (2000): The 'adrenaline hypothesis' of hypertension revisited: evidence for adrenaline release from the heart of patients with essential hypertension. J Hypertens., 18: 717-723.

29. Thomas W. L., Sandra Z., Dirk J. D., Wouter T., Gooitzen A., Frans B., Pieter D. V. and Anton H. M. (2002): Epinephrine in the Heart. Circulat., 106: 860.

30. El-Kady M. M. Z., Meki M. AR., Anwar M. M. and AbdelGany S. (1997): Clinical and biochemical evaluation of some enzymatic activities in scorpion envenomed children. Assiut Medic. J., 21 (4): 217-228.

31. Murthy R. K. and Zare A. M. (2002): Scorpion antivenom reverse metabolic, electrocardiographic, and hormonal disturbances caused by the Indian red scorpion Mesobuthus tamulus concanesis, Pocock Envenomation. J. Venom. Anim. Toxi., 8 (1).

32. Reid I. A. (1992): Interactions between Ang II, sympathetic nervous system, and baroreceptor reflexes in regulation of blood pressure. Am. J. Physiol., 262 (25): 763-778.

33. Victor JD and Richard EP. (1992): Renin-angiotensin system, in Fozzard HA (ed): The heart and cardiovascular system. New York, Raven Press, 18171849.

34. Weber KT. (1999): Angiotensin II and connective tissue: homeostasis and reciprocal regulation. Regul. Pept., 82: 1-17.

35. Müller D. N., Jürgen B., Karl F. H., Duska D., Olivier C., Joël Ménard and Friedrich C. L. (1997): Vascular AngiotensinConverting Enzyme Expression Regulates Local Angiotensin II. Hypertens., 29: 98.

36. Karnad DR. (1998): Haemodynamic patterns in patients with scorpion envenomation. Heart, 79: 485489.

37. Brown J. N. and Roberts J. L. (2001): Histamine, bradykinin and their antagonists. In: Goodman and Gilman's: The pharmacological basis of therapeutics, Tenth Edition: Page 645-667.

38. Campbell D. J. (2000): Towards understanding the kallikrein-kinin system: insights from measurement of kinin peptides. Braz J Med Biol Res., 33 (6): 665-677.

39. McGiff JC., Carroll MA., and Escalante B. (1991): Arachidonate metabolites and kinins in blood pressure regulation. Hypertens., 18: 150157.

40. Ismail M., Fantani A. J. Y. and Dabess T. T. (1992): Experimental treatment protocols for scorpion envenomation: A review of common therapy and an effect of kallikrein kinin 
inhibitors. Toxico., 32: 15991618.

41. Chen Y., Dongsoo K., Toru A. and Bradford C. B. (2003): Functional interplay between Ang II and Nitric oxide, arteriosclerosis, thrombosis, and vascular biology. Am. Heart Associat., 23: 26.

42. Machenzie I. M., Garrad CS. and Young J.D. (2001): Indices of nitric oxide synthesis and outcome in critically ill patients. Anaethes., 56: 326-330.

43. Busse R., Mulsch A., Fleming I. and Hedcer $M$. (1993): Mechanism of nitric oxide release from the vascular endothelium. Circulat., 87: 18-25.

44. Luscher TF., Tanner FC., Tschudi MR. and Noll G. (1993): Endothelial dysfunction in coronary artery disease. Annu Rev Med., 44: 395-418.

45. Mombouli JV. (1997): ACE inhibition, endothelial function and coronary artery lesions. Role of kinins and nitric oxide. Drug., 54 (5): 12-22.

46. Teixeira CE., de Oliveira JF., Baracat JS., Priviero FB., Okuyama CE., Rodrigues Netto
N Jr., Fregonesi A., Antunes E. and De Nucci G. (2004): Nitric oxide release from human corpus cavernosum induced by a purified scorpion toxin. Urology, 63 (1): 184-189.

47. Perrin C. W., Tomoatsu M. and Agarwal A. K. (1997): 11ßHydroxysteroid dehydrogenase and the syndrome of apparent mineralocorticoid excess. Endocrine Revie., 18 (1): 135156.

48. Farman N. and Marie-Edith $\mathbf{R}$. (2001): Multiple aspects of mineralocorticoid selectivity. Am. J. Physiol. Renal Physiol., 280 (2): 181-192.

49. Garrison JC. and Peach M. J.(1992): Renin and angiotensin. In: The pharmacological basis of therapeutics. Goodman Gilman A.; Rall T. W; Niles A. S.; Taylor P. Eds., 1: 746-763.

50. Semir R., Abroug F., Haguiga H., Jaafoure M., Boujdaire R. and Bouchoucha S. (1995): Right ventricular dysfunction following severe scorpion envenomation in children. Ches., 108: 682-687. 


\section{بعض الوسائط البيوكيميائية المؤئرة على الأوعية الاموية في الأطفال

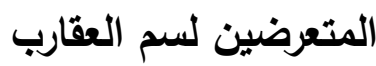

$$
\begin{aligned}
& \text { رضان عبد العال سبد"و زبنب محد محي الدين*"* و عبد الرحبي محدد عبد الحفبظ" }
\end{aligned}
$$

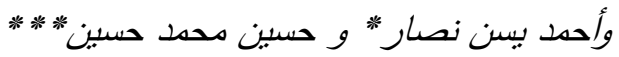

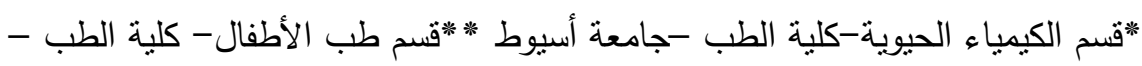

$$
\begin{aligned}
& \text { جامعة أسيوط *** * قسم الكيمياء الحيوية-كلية الطب -جامعة الأزهر -فرع أسيوط الطفية }
\end{aligned}
$$

يعد للدغ العقارب في الأطفال من الحالات القانلة حيث يسبب ثلقائيا إفراز الأدرينالين

والنورادرينالين و بيبتيد الأنجيوتنسين-r وهرمون الجلوكاجون والكورتزول بنسب هائلة. ويحدث نتيجة

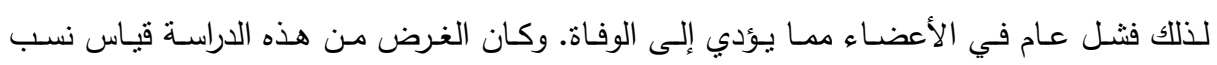

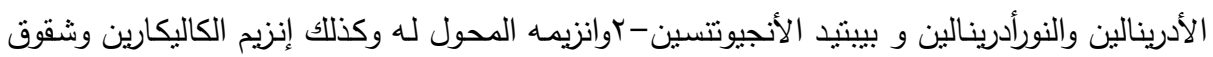

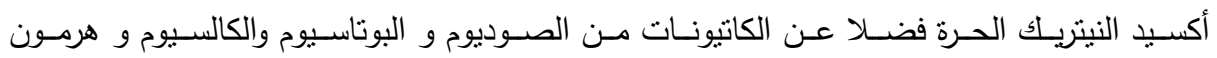
الألدوستيرون المنظم لها في الدم للأطفال المصابين بلداغ العقرب. وكذللك تقييم العلاقة بين هذه

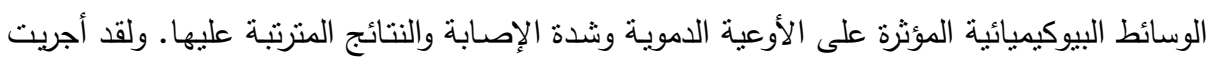
هذه الدراسة على أربعين طفل ممن تعرضوا للاغ من الجنسين تراوحت أعمارهم بين السنة والثالثة التائة

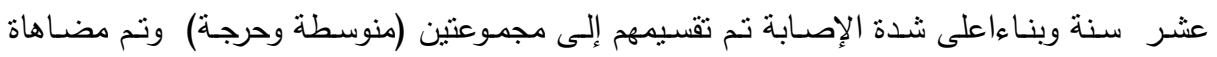

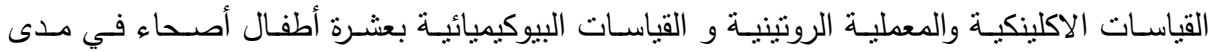

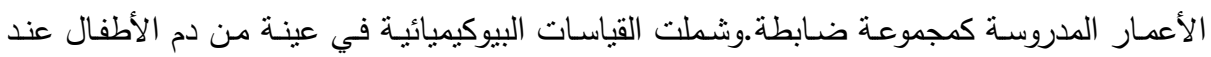

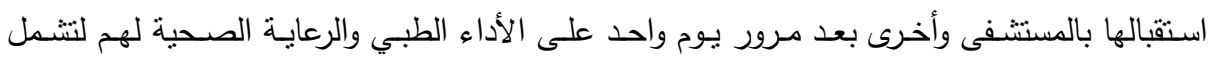

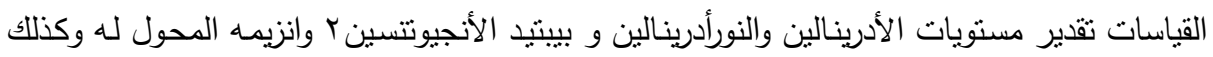

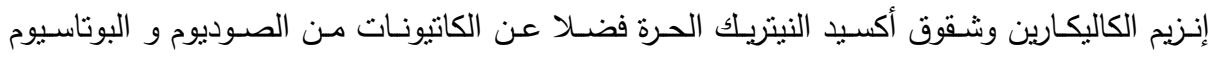
والكالسيوم و هرمون الألدوستيرون المنظم لها. وكانت النتائج البيوكيميائية المقاسـة عند الدخول

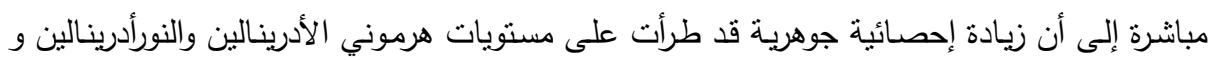

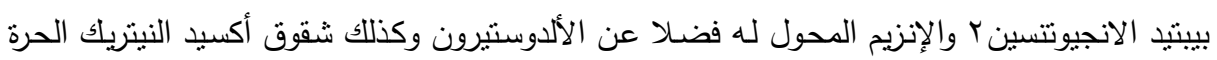

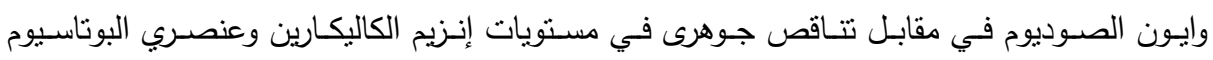
والكالسيوم مقارنة بمجموعة الأطفال الأصحاء. وبعد مرور يوم واحد من دخول المستثفى فقد ظلت 
مسنويات بيبتيد الأنجيوتنسين ب والإنزيم الحسول له فضـلا عن شقوق أكسيد النيتريك الحرة مرتفعـة

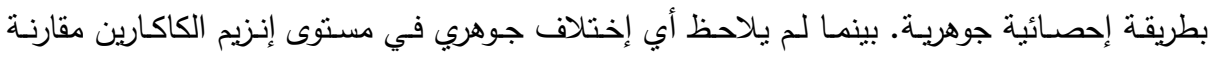
بمجموعة الأطفال الأصحاء. ومما سبق يتبين لنا الدور الهام الذي تلعبه هذه الوسائط البيوكيميائية

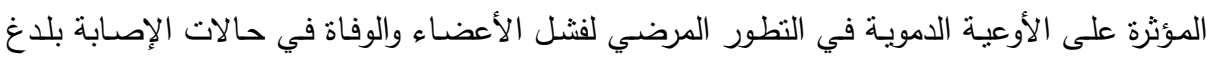

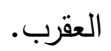

